\title{
Interactive comment on "Ostracods as ecological and isotopic indicators of lake water salinity changes: The Lake Van example" by Jeremy McCormack et al.
}

Jeremy McCormack et al.

jeremy.mccormack@rub.de

Received and published: 15 March 2019

Anonymous Referee \#3 Referee comment: General comments: The presented new dataset provides a useful addition of previous investigations of the lake Van (Turkey). Previous studies of the two cores, containing in total 600.000 years lake history, mainly focused on pollen and geochemical data provides a very excellent geo-bio-climate archive and is unique over the world. Ostracod investigations are a very important tool to figure out lake history and at least climate record of these huge archive. Authors used not only the species diversity (poorly in this case) but also valve morphology and shell geochemistry. These are powerful tools, especially if the ostracod diversity is 
very poor like in this case. If the authors could show that noding of the limnocytherids is (also) environmental controlled that's really important. It's a pity that the authors only investigated the upper $150 \mathrm{ky}$. It would be exciting to see what happened in the older sections.

Authors response: We thank the referee for his/her approval of our manuscript and for the most enthusiastic encouragement for further work! We limited our first investigation of ostracod valves in sedimentary profiles of Lake Van to the last $150 \mathrm{kyr}$ of the record, due to the chosen resolution and the very time-consuming processes of sample sieving (256 samples) and valve picking and counting (23,168 valves). We ourselves are curious to see what happens in the older sediments and we are determined to find it out in future studies!

Referee comment: Specific comments: The authors should distinguish between noded Limnocythere sp. and Limnocythere inopinata to exclude species depending noding.

Authors response: This is a valid comment. The as of yet not described Limnocythere $\mathrm{sp}$. A was excluded from the node counting, as it never shows nodes and is easily distinguishable from other limnocytherinae species. Because Limnocythere inopinata is a polymorphic species and valve morphology is variable throughout the studied interval, the differentiation between Limnocythere inopinata and other limnocytherinae species is in Lake Van very complex, and we currently prepare a separate manuscript on the topic.

Referee comment: The authors should present a cross plot of oxygen isotopes and nodding to present this very important context.

Authors response: While the idea is very intriguing, at the present we are technically not able to put it into practice. We were not able to measure noded versus unnoded valves within a given sample, due to the often low amount of Limnocythere inopinata valves and their low thickness in many samples. Additionally, in many cases it was not possible to remove foreign sedimentary matter accumulated within the hollow nodes,

Printer-friendly version

Discussion paper 
without breaking the valves. Limnocythere inopinata valves showed no consistent differences in $\delta 180$ and $\delta 13 \mathrm{C}$ that could be related to reticulation and given that the node formation process is likely related to the difficulty of achieving an osmotic balance, we assume the formation of nodes does not impact the valve isotopy. Still, as soon as we have ample material for independent measurements, we will test this hypothesis.

Referee comment: The authors only mentioned the three dominant taxa and refer to a subsequent paper treating the limnocytherid fauna. However, it is important to have information about the ostracod diversity in the current contribution.

Authors response: The ostracod diversity is very low and, throughout the studied interval comprises three dominant taxa Candona sp., Limnocythere inopinata and Limnocythere sp. A (Figure 1). Already from the relative abundance of these three taxa we were able to demonstrate an environmental control on ostracod diversity. The present manuscript is the first documentation of, until now largely overlooked, Lake Van ostracods and their application as multi-proxy salinity archives. Working on this data set we have only realised the intricate complexity of limnocytherid species present in Lake Van sediments and we feel that a detailed investigation of subtle differences in limnocytherinae species and morphotypes would be too wide a scope for this paper and a too specific topic for Biogeosciences. The paper in preparation is aimed for a microfossil/micropalaeontology-oriented journal.

Referee comment: However, congratulation to this very nice study!

Authors response: Thank you for your positive comments. They are very much appreciated.

Interactive comment on Biogeosciences Discuss., https://doi.org/10.5194/bg-2018-476, 2019. 